\title{
Hubungan Antara Sikap Pelajar dengan Tahap Tekanan Guru Program Pendidikan Inklusif dalam Pendidikan Teknikal dan Vokasional
}

\section{The Relationship between Students Attitude and Stress Level of Inclusive Education Teachers in Technical and Vocational Education}

\author{
Arihasnida Ariffin ${ }^{1 *}$, Nur Fatin Nadiah Nordian" ${ }^{1}$, Norhasyimah Hamzah", \\ Normah Zakaria $^{1}$, Siti Nur Kamariah Rubani ${ }^{1}$
}

${ }^{1}$ Universiti Tun Hussein Onn Malaysia, Batu Pahat, 86400, MALAYSIA

*Corresponding Author

DOI: https://doi.org/10.30880/ojtp.2021.06.01.002

Received 30 April 2020; Accepted 10 November 2020; Available online 31 March 2021

\begin{abstract}
Abstrak: Permasalahan timbul dalam kalangan guru-guru Program Pendidikan Inklusif dalam Mata Pelajaran Vokasional (MPV) apabila terhasilnya guru yang gagal mengawal diri akibat tekanan yang melampau memberi kesan kepada perhubungan antara guru PPI, pelajar dan juga kualiti dalam aspek pengajaran dan pembelajaran. Kajian ini dijalankan bagi mengenal pasti hubungan antara sikap pelajar dengan tahap tekanan guru PPI dalam Mata Pelajaran Vokasional di Sekolah Menengah Kebangsaan (SMK) di sekitar Negeri Johor. Reka bentuk kajian ini adalah kajian tinjauan berbentuk kuantitatif menggunakan borang soal selidik sebagai instrumen kajian. Responden terdiri daripada 113 guru PPI yang mengajar subjek MPV yang dipilih secara rawak mudah. Hasil daripada kajian ini mendapati bahawa terdapat hubungan yang signifikan antara sikap pelajar dengan tahap tekanan guru PPI. Pemantauan terhadap persepsi guru adalah amat penting bukan sahaja untuk Mata Pelajaran Vokasional malahan subjek-subjek lain dan memberikan kebaikan serta kejayaan kepada setiap program dalam bidang Pendidikan Khas di Malaysia.
\end{abstract}

Kata Kunci: Program Pendidikan Inklusif (PPI), Mata Pelajaran Vokasional, kerenah pelajar, tekanan

\begin{abstract}
Problems arise among Inclusive Education Programme teachers in the subject of Vocational Subjects (MPVs) when the result of a teacher who fails to control themselves due to stress that affects the relationship between teachers, students as well as quality in the teaching and learning. This study was conducted to identify the relationship between student attitude and stress level among teachers in the Vocational Subject at Sekolah Menengah Kebangsaan (SMK) around Johor. The design of this study is a survey study involving 113 randomly selected respondents around Johor by using questionnaire as the instrument of study. Respondents consist of PPI teachers who teach the subject of MPV. The result of this study shown significant relationship between student attitude and stress level among PPI teachers. Monitoring of teacher perceptions is especially important not only for MPV but also other subjects in order to restore imperfections and to provide benefits and success to every program in Special Education in Malaysia.
\end{abstract}

Keywords : Inclusive Education Program, Vocational Subject, student attitude, stress level 


\section{Pengenalan}

Perubahan sistem pendidikan pada masa ini telah memberi impak atau kesan kepada Program Pendidikan Inklusif serta telah menyebabkan peningkatan tekanan dengan beban tugas yang sedia ada bertambah terutamanya dalam penyediaan Alat Bantuan Mengajar dan bahan-bahan pengajaran terhadap guru PPI yang mengajar subjek MPV ditambah pula dengan pelbagai kerenah pelajar yang terpaksa dihadapi oleh guru (Yahaya, Ramli dan Ismail, 2010). Ini disokong oleh Mohd Amin dan Mohd Yasin (2016) yang mengatakan bahawa perubahan ini menyebabkan guru PPI subjek MPV dalam bidang teknik dan vokasional bukan sahaja berkemahiran untuk menyampaikan ilmu kepada pelajar berkeperluan khas sebaliknya dapat melatih perkembangan diri pelajar berkenaan secara seimbang dari segi jasmani, emosi, rohani, intelek dan sahsiah. Ini secara tidak langsung telah menambahkan tahap tekanan dan beban kerja kepada guru-guru PPI subjek MPV.

Menurut Sipon (2007) pula, apabila terhasilnya guru PPI subjek MPV yang gagal mengawal diri akibat tekanan akan memberi kesan kepada perhubungan antara guru PPI subjek MPV dengan pelajar dan juga kualiti dalam aspek pengajaran dan pembelajaran guru itu sendiri. Keadaan ini sekaligus boleh menjejaskan kualiti pendidikan dan juga profesion perguruan dan ini secara tidak langsung akan membantutkan usaha mewujudkan sebuah masyarakat berpendidikan MPV yang mampu membawa negara ke tahap yang lebih cemerlang dan gemilang khususnya untuk meningkatkan mutu pendidikan (Othman dan Omar, 2014). Tahap tekanan kerja yang berlebihan akan membawa kepada rasa tidak senang hati terhadap kerja yang dilakukan dan akhirnya sikap suka mengelak dan mengabaikan kerja akan berlaku (Yahaya, Ramli dan Ismail, 2010). Menurut Omar (1996), akibatnya ia juga akan menyebabkan suasana kerja yang teruk dan membawa kepada keinginan untuk meninggalkan profesion keguruan (Omar, 1996). Isu bebanan kerja dalam kalangan guru-guru PPI subjek MPV perlu diberi perhatian yang serius kerana tahap bebanan kerja yang semakin meningkat boleh membawa kepada pelbagai kesan negatif seperti prestasi kerja yang rendah, kurang memberi komitmen, tidak mempunyai motivasi serta kualiti pengajaran dan pembelajaran di bilik darjah akan merosot (Zakaria, 2014). Di samping itu, masalah bebanan kerja ini juga boleh menyebabkan guru PPI subjek MPV menghidap penyakit mental dan fizikal, serta menjadi punca utama pramatang persaraan dalam kalangan guru PPI subjek MPV (Fong, 2004). Ini disokong dan diperkuatkan lagi apabila menurut kenyataan Kesatuan Perkhidmatan Pendidikan Kebangsaan (KPPK), permasalahan perkhidmatan, tekanan kerja, bebanan kerja, konflik peranan, kekaburan peranan, ketiadaan satu sistem sokongan sosial dari pengetua dan rakan sekerja yang kukuh dan rangkaian masalah lain yang tidak diselesaikan dengan adil dan memuaskan telah mengakibatkan ramai guru guru PPI subjek MPV meletakkan jawatan, bertukar ke profesion lain atau memohon bersara awal dari profesion perguruan (Ambotang dan Mohd Hashim, 2010).

Bukan itu sahaja, hubungan kerjasama tersebut tidak dapat dizahirkan sepenuhnya apabila tiada khidmat guru yang disediakan oleh pihak unit pendidikan khas sekolah di kebanyakan program inklusif yang dijalankan (Mohd. Hanafi, Hasnah dan Shahruddin, 2008). Ini menambahkan lagi bebanan dihadapi oleh guru PPI subjek MPV yang terlibat dengan program ini apabila mereka perlu untuk mencari input sendiri berkaitan pengajaran dalam PPI. Kerjasama antara guru pendidikan khas dan guru PPI subjek MPV dalam mengendalikan program pendidikan inklusif (PPI) perlu untuk mengurangkan masalah dan dapat banyak membantu guru perdana mengendalikan proses pengajaran dan pembelajaran dengan baik. Ini mendapat sokongan kenyataan oleh Zailani (2011) yang menyatakan bahawa guru resos dan guru PPI subjek MPV perlu menggunakan kaedah koperatif dan kolaboratif dalam mengendalikan kelas inklusif. Selain itu, melalui para pengkaji lepas rata-ratanya menyatakan antara isu yang turut memberi kesan kepada guru PPI subjek MPV adalah kerenah pelajar berpendidikan khas. Kerenah pelajar di dalam kelas seperti kurang menghormati guru, kurang penumpuan di dalam kelas, masalah disiplin, kurang bermotivasi dan tidak menyiapkan kerja sekolah didapati telah menyebabkan guru PPI subjek MPV berasa tertekan setiap kali memasuki kelas atau bengkel (Fun, 2008; Kim, 2006; Tang dan Yeung, 1999; Montgomery dan Rupp, 2005). Akibat sikap pelajar, guru guru PPI subjek MPV sering keletihan dan tidak bersemangat untuk mengajar. Kesukaran yang dihadapi oleh guru PPI subjek MPV dalam berhadapan dengan pelbagai karenah pelajar telah menyebabkan sebahagian guru mengalami burnout iaitu kehausan fizikal dan emosi, hilang daya minat terhadap kerjaya dan sering mengasingkan diri (Hashim dan Ibrahim, 2007).

\section{Kerangka Konsep Kajian}

Kerangka konsep adalah kerangka yang digunakan oleh pengkaji sebagai panduan dan halatuju pengkaji untuk menjalankan kajian ini. Ia juga adalah kerangka yang mengandungi komponen-komponen penting yang berkaitan dengan kajian yang dijalankan bagi memperjelaskan perhubungan antara konsep-konsep abstrak dalam bentuk hipotesis (Rosma, 2013). Sebelum membina kerangka konsep, beberapa maklumat mengenai model proses pendidikan dan model tegangan atau tekanan telah dikumpul. Terdapat beberapa model tekanan yang telah digunapakai oleh ahli-ahli psikologi (Adi Zuraini, 2003). Bermula dengan model pertama iaitu Selye (1976) yang menyatakan bahawa tegangan telah dianggap sebagai satu gerakbalas dan merupakan satu angkubah (pembolehubah) bersandar. Namun begitu, muncul pula model kedua dalam pendekatan yang membawa kepada anggapan tegangan sebagai pemboleh ubah bebas. Tegangan atau tekanan ini telah dianggap mewakili rangsangan persekitaran yang luar daripada individu. Manakala model yang ketiga pula menganggap tegangan atau tekanan adalah sebagai satu proses psikologi yang terjadi apabila adanya rangsangan dan tindakbalas. 
Rajah 1 - Model proses pendidikan (Alias Baba, 1989)

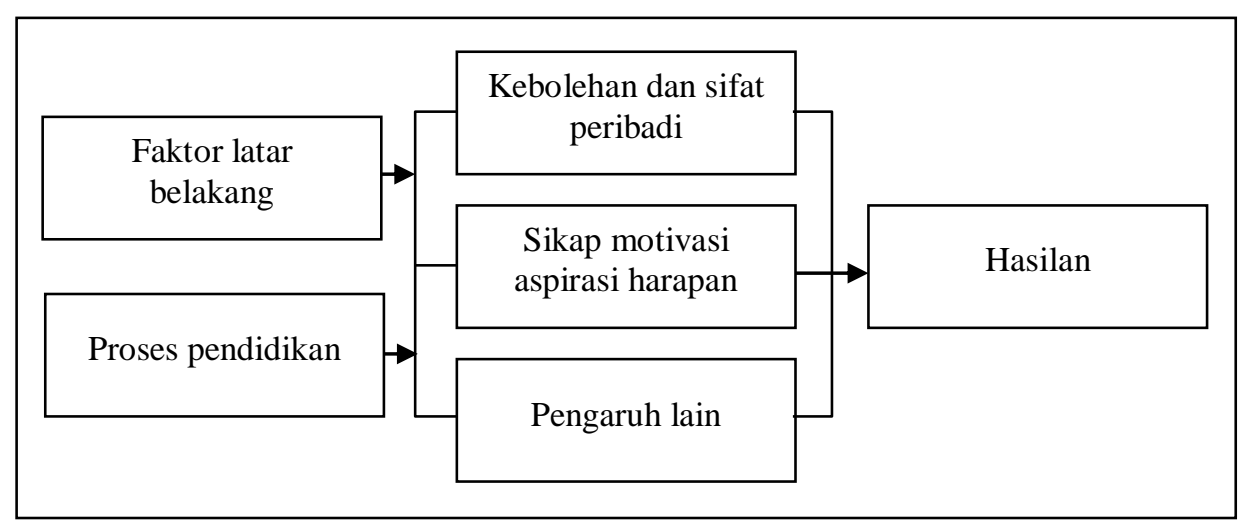

Rajah 1 menunjukkan model proses pendidikan yang menerangkan terdapat tiga jenis kumpulan yang akan memberi kesan kepada hasil pembelajaran (Alias Baba, 1989). Kumpulan pertama digolongkan sebagai input daripada guru yang terdiri daripada faktor latar belakang, faktor kebolehan dan sifat peribadi. Di dalam faktor latar belakang, ia merangkumi faktor umur, jantina dan bangsa. Proses pendidikan yang terdiri daripada faktor-faktor seperti kaedah pengajaran, aktiviti pembelajaran, suasana bilik darjah dan personaliti guru.

Rajah 2 - Kerangka konsep kajian

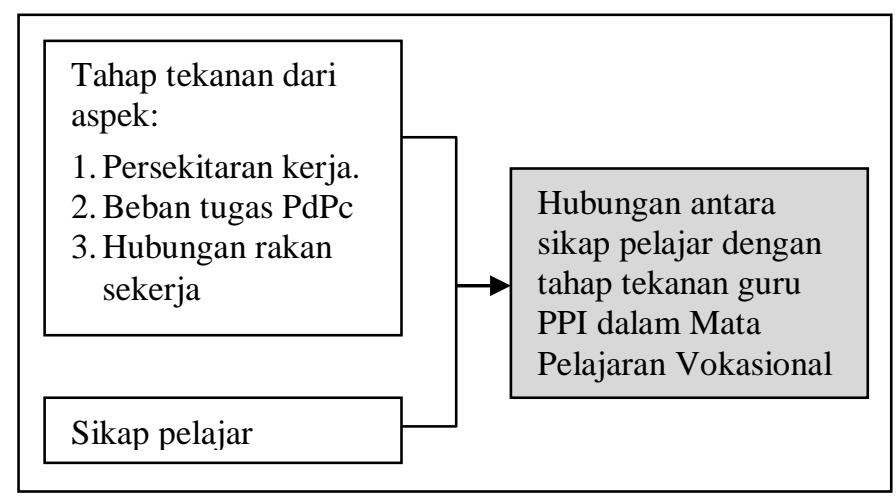

Rajah 2 menunjukkan kerangka konsep kajian yang direka bentuk semula berdasarkan model proses pendidikan yang diubahsuai dan disesuaikan dengan kajian penyelidik. Terdapat dua jenis faktor utama yang akan memberi kesan kepada persepsi guru-guru PPI. Faktor yang pertama adalah tahap tekanan yang merangkumi tiga pecahan faktor kecil iaitu persekitaran kerja, beban tugas melalui PdPc dan hubungan rakan kerja. Bagi faktor yang kedua adalah sikap pelajar iaitu sebagai satu proses psikologi yang hadir di antara ransangan dan memberi tindak balas terhadap hasilan kajian iaitu hubungan antara sikap pelajar dengan tahap tekanan guru PPI dalam Mata Pelajaran Vokasional.

\subsection{Tahap Tekanan}

Tekanan merupakan satu penyakit yang selalu dikaitkan dengan kesihatan mental dan ia sering menyerang penduduk masyarakat pada hari ini (Halim, 2013). Kesihatan mental seperti yang dimaksudkan oleh Pertubuhan Kesihatan Sedunia (WHO) adalah kebolehan mengekalkan hubungan yang harmoni dengan orang lain. "Kebolehan dalam mengambil bahagian di dalam aktiviti kemasyarakatan dan kebolehan untuk menyumbangkan khidmat kepada masyarakat" (Kempen Cara Hidup Sihat, Kementerian Malaysia, 2002). Bukan itu sahaja, pelbagai maksud atau definisi telah diterjemahkan oleh beberapa orang untuk menghuraikan secara terperinci tentang makna tekanan. Menurut Smither (1994), tekanan adalah sebagai respons fisilogikal dan fisiologikal ke atas permintaan terhadap seseorang. Manakala Fontana (1989) telah memberi definisi bahawa tekanan sebagai permintaan yang dibuat ke atas keupayaan penyesuaian minda dan badan seterusnya menjelaskan sekiranya keupayaan seseorang itu dapat menangani permintaan itu, maka tekanan tersebut akan menghasilkan kesan positif.

Profesion guru adalah domain utama yang diberi amanah dan dipertanggungjawabkan untuk menyebarkan proses penerapan dan penyampaian ilmu kepada anak-anak didik, tanpa mengambil kira kerelaan mereka (Yahaya, Ramli dan Ismail, 2010). Para guru dituntut untuk membangunkan diri dengan sebarang bentuk perubahan serta perbaharuan yang berlaku dalam bidang pendidikan dari semasa ke semasa. Situasi tersebut secara umumnya telah memberi kesan apabila guru-guru terpaksa berhadapan dengan pelbagai tanggungjawab yang lebih mencabar, lebih berat dan semakin 
kompleks (Mohamed, 2001). Menurut Said Ambotang et al. (2008), dalam jangka masa 30 tahun ini, terdapat ramai pengkaji yang telah melakukan kajian berkaitan dengan tekanan dalam kalangan guru PPI dalam subjek MPV. Terdapat lebih daripada satu pertiga guru di Amerika Syarikat mengalami tekanan yang melampau (Pithers dan Soden, 1999; Van Dick dan Wagner, 2001). Bahkan menurut pendapat Kyriacou (2001) mengatakan bahawa tekanan guru PPI adalah disebabkan oleh kuantiti bebanan tugas kerja yang berat dan suasana kerja yang kurang memuaskan. Menurut kenyataan akhbar Utusan Malaysia bertarikh 13 Disember 2012 menyatakan bahawa 530 daripada jumlah guru di seluruh negara dikenal pasti berdepan dengan masalah mental. Melalui kenyataan tersebut, Kementerian Pendidikan Malaysia (KPM) amat mengambil perhatian yang serius terhadap masalah tersebut keranan khuatir boleh mengganggu proses pengajaran serta pembelajaran di dalam bilik darjah.

\subsection{Sikap Pelajar}

Perkataan kerenah pelajar tidak asing daripada pendengaran telinga para guru PPI dalam subjek MPV. Menurut Panitia Bahasa Melayu (2011) kata ganti lain bagi kerenah pelajar adalah ragam, tingkah laku dan perangai pelajar. Kajian berkaitan dengan masalah tingkah laku dan kerenah pelajar, boleh menimbulkan pelbagai kerenah yang mengganggu kelancaran pengajaran dan pembelajaran dalam bilik darjah disamping menimbulkan pelbagai jenis masalah disiplin berkaitan dengan pelajar berkeperluan khas dengan pihak pentadbir dan guru-guru (Datu Iskandar, 2013). Menurut kajian Mikail (2012) dan Admin (2000) terdapat tiga jenis pelajar MBK yang dapat digolongkan bagi mengenal pasti kerenah atau kelakuan pelajar berkeperluan khas tersebut. Pertama adalah kategori masalah dari segi pembelajaran iaitu pelajar yang telah didiagnosis oleh doktor tergolong dalam pelajar yang mempunyai masalah pembelajaran. Antara contoh MBK yang tergolong dalam kategori tersebut adalah pelajar yang menghidap autism, ADHD, terencat akal, sindrom down, disleksia, dispraksia dan diskakulia. Pelajar MBK yang tergolong dalam golongan autisme, mempunyai pola perlakuan yang unik iaitu gemar memutar-mutar barang sambil berkhayal dan terlalu menyayangi sesuatu objek sehinga sukar dipisahkan daripadanya. Selain itu, mereka memerlukan tempoh masa untuk menumpukan perhatian terhadap sesuatu perkara amat singkat dan kadang-kadang tidak berminat dengan kemahiran yang diajar. Mereka juga sering mengulangi soalan yang diajukan dan tidak tahu erti bahaya.

Pelajar berkeperluan khas yang tergolong dalam golongan disleksia juga mempunyai kerenah yang unik. Antaranya adalah germar berkhayal, menangis dan ketawa secara tiba-tiba, tempoh masa untuk menumpukan perhatian kepada sesuatu perkara adalah singkat, kadang-kadang kurang keyakinan diri terhadap sesuatu perkara dan gemar menggigit jari dan merenung buku seolah-olah tidak faham. Tahap kecergasan pada pelajar ini adalah pada tahap normal, namun pada kebanyakan pelajar disleksia tidak dapt mengimbangi daya mengingati bentuk huruf, bunyi huruf dan gabungan perkataan. Antaranya adalah huruf 'b', 'd' dan 'p', 'q'. Walau bagaimanapun, mereka mempunyai bakat dan berkebolehan seperti kreatif, berfikiran lateral, berimaginasi dan pandai membuat visualisasi. Kerenah bagi pelajar berkeperluan khas yang mengalami sindrom down pula mempunyai kerenah suka untuk menyayangi sesuatu objek atau manusia sehingga sukar untuk dipisahkan. Mereka suka untuk bersendirian dan menganggap manusia sebagai objek dan hanya berinteraksi bila didekati dengan cara-cara tertentu dan dengan individu yang disukai.

Kategori kedua adalah pelajar MBK masalah pendengaran. Kerenah pelajar dalam kelompok ini pula mempunyai masalah kurang keyakinan diri, kurang memberi perhatian, selalu berkhayal dan kurang melibatkan diri dalam perbincangan atau kumpulan, (Mikail, 2012). Kategori yang ketiga adalah pelajar MBK masalah penglihatan iaitu astigmatisme, strabismus, amblipia, diplopia, glaucoma, myopia dan hyperopia. Menurut Mikail (2012) dan Admin (2000) bagi pelajar yang mempunyai masalah penglihatan ini mereka mempunyai masalah kurang keyakinan diri, dan kurang melibatkan diri dalam perbincangan atau kumpulan. Kesan yang kerap berlaku adalah pelajar MBK tersebut mengalami masalah kemurungan dan enggan mengikut arahan yang diberikan oleh guru serta tidak mahu untuk bergaul dengan pelajar perdana.

\section{Persoalan Kajian}

Persoalan kajian ini adalah "Adakah terdapat hubungan yang signifikan antara kerenah pelajar dengan tahap tekanan guru PPI dalam subjek MPV bagi Program Pendidikan Inklusif (PPI) dalam subjek MPV?”

\section{Metodologi Kajian}

Reka bentuk kajian ini adalah kajian tinjauan melalui kaedah kuantitatif. Mohd Najib (1998) mengatakan bahawa kajian tinjauan adalah sesuai digunakan dalam penyelidikan yang bermatlamat untuk menerangkan sesuatu masalah atau fenomena yang sedang terjadi. Manakala kaedah persampelan kajian adalah persampelan rawak mudah iaitu pemilihan guru hanya terlibat dalam program PPI sahaja menjadi sampel kajian. Jumlah guru sebagai responden adalah seramai 113 orang yang mengajar Mata Pelajaran Vokasional. Lapan belas buah lokasi sekolah telah dipilih di sekitar Negeri Johor secara rawak melalui atas talian (web). Instrumen kajian adalah borang soal selidik yang mempunyai 40 item telah digunakan bagi mengenal pasti hubungan antara sikap pelajar dengan tahap tekanan guru PPI dalam Mata Pelajaran Vokasional. Kajian rintis dilakukan terhadap 30 orang guru program PPI dari luar negeri Johor yang mempunyai ciri-ciri yang hampir sama. Nilai Alpha Cronbach yang diperoleh adalah 0.786 iaitu pada tahap 
kebolehpercayaan yang sangat baik. Pengkaji menggunakan Skala Likert empat mata di dalam borang soal selidik. Ini memudahkan responden untuk menjawab dan memilih jawapan yang paling tepat berdasarkan pandangan, pendapat dan persepsi mereka terhadap soalan tersebut (Idris, 2010). Pengkaji menggunakan statistik inferensi yang merupakan kaedah statistik yang betujuan untuk membuat hubungan antara sesuatu faktor. Dalam kajian ini pengkaji telah melalui kaedah statistik Kolerasi Pearson untuk mendapatkan perkaitan hubungan antara kedua pembolehubah iaitu tahap tekanan guru PPI dan sikap pelajar.

\section{Dapatan Kajian}

Berikut adalah merupakan keputusan hubungan inferensi bagi ujian kolerasi antara sikap pelajar dengan tahap tekanan bagi guru PPI untuk Mata Pelajaran Vokasional. Berdasarkan Jadual 1 di bawah, didapati bahawa nilai pekali korelasi, r bagi aspek kerenah pelajar dengan tahap tekanan guru PPI dengan Mata Pelajaran Vokasional adalah bersamaan dengan positif 0.411 dengan nilai signifikannya adalah kurang daripada 0.001. Nilai signifikan ini menunjukkan bahawa kebarangkalian untuk mendapatkan nilai signifikan korelasi melalui sampel yang berjumlah 113 bahawa hubungan kolerasi antara kerenah pelajar dan aspek tahap tekanan adalah rendah.

Jadual 1 - Korelasi tahap tekanan guru PPI dengan sikap pelajar

\begin{tabular}{lccc}
\hline & & Tahap Tekanan & Sikap Pelajar \\
\hline \multirow{3}{*}{ Sikap Pelajar } & Kolerasi Pearson & $0.411^{* *}$ & 0.000 \\
\cline { 2 - 4 } & Signifikan (2-tailed) & 0.000 & $411^{* *}$ \\
\cline { 2 - 4 } & $\mathrm{N}$ & 113 & 113 \\
\hline
\end{tabular}

Manakala nilai $\mathrm{p}<0.001$ adalah lebih kecil daripada 0.05 . Oleh yang demikian, terdapat hubungan yang signifikan antara sikap pelajar dengan tahap tekanan guru PPI dalam Mata Pelajaran Vokasional bagi program PPI adalah bersetuju untuk diterima. Dengan ini secara tidak langsung telah menolak hipotesis Null (Ho) iaitu tidak terdapat hubungan yang signifikan antara kerenah pelajar dengan tahap stess guru PPI dalam subjek MPV bagi program PPI. Oleh kerana keputusan ujian korelasi menunjukkan terdapat hubungan yang signifikan, maka dapat disimpulkan di sini bahawa aspek tekanan dengan sikap pelajar mempunyai hubungan adalah pada tahap yang rendah.

\section{Perbincangan}

Berdasarkan dapatan kajian mendapati bahawa terdapat hubungan yang signifikan di antara kerenah pelajar dan tahap tekanan yang dialami oleh guru PPI. Hubungan ini terhasil adalah mungkin disebabkan ketidakupayaan guru PPI untuk menangani kerenah pelajar di samping tekanan-tekanan lain yang dihadapi oleh mereka. Ini disokong oleh dapatan kajian daripada Noran, Lope Pihie dan Mahyuddin (2002) yang menyatakan kedua-dua asbab kerana pelajar dan tahap tekanan adalah positif dan signifikan.

Melalui konstruk beban tugas dari segi PdPc, menunjukkan yang tahap tekanan yang paling tinggi terjadi apabila guru program PPI bagi subjek MPV terpaksa melakukan pelbagai tugas berkaitan dengan perkeranian. Beban tugas melalui PdPc merujuk kepada tugas-tugas dalam PdPc dan juga tugas-tugas sampingan sekolah yang diarahkan oleh pihak pentadbir. Ini disokong dengan pendapat Ahmad Azhari (2010) yang mengatakan bahawa guru yang menjalankan tugas secara berlebihan dan melebihi tahap kemampuan diri mudah mendapat tekanan. Di samping itu, perubahan kaedah penilaian yang dilaksanakan di sekolah pada masa kini sedikit sebanyak memberi kesan terhadap tahap tekanan kerja bagi setiap guru-guru di sekolah. Bagi konstruk persekitaran tempat kerja, item suasana pelajar di dalam kelas pengajaran sewaktu subjek MPV berlangsung menunjukkan tahap tekanan yang paling tinggi berbanding item yang lain. Ini selaras dengan dapatan kajian Ali (2011) yang mengatakan bahawa faktor-faktor tekanan adalah meliputi faktor bebanan kerja, faktor perhubungan pekerja, faktor peranan dalam organisasi dan faktor persekitaran. Bohari, Ahmad dan Ramli (2011) yang mengatakan suasana persekitaran bilik darjah memainkan peranan yang penting terhadap emosi guru yang mengajar dan ini berkemungkinan mendorong guru yng mengajar mudah untuk menjadi baran dan memarahi para pelajar. Konstruk hubungan rakan sekerja telah menyumbang kepada tahap tekanan yang rendah dalam kajian ini. Kajian Trendal (1989) yang menyatakan apabila terdapat hubungan yang positif dalam kalangan pekerja dalam sesuatu institusi dan adanya rakan sekerja yang boleh dibawa berbincang bagi mengenalpasti masalah yang mereka hadapi dan cadangan jalan penyelesaian.

Melalui min skor item-item dalam kerenah pelajar menunjukkan tahap tekanan yang dihadapi oleh guru-guru PPI adalah pada tahap rendah. Dapatan kajian ini disangkal oleh dapatan pengkaji luar negara iaitu Manthei dan Solman (2005); Hart et al. (1995) dan Merret \& Wheldall (1993) bahawa faktor kerenah pelajar merupakan faktor utama tekanan kerja oleh para guru. Pengkaji berpendapat bahawa ini adalah disebabkan psikologi bagi pelajar berkeperluan khas yang mempunyai sifat rendah diri akan perbezaan keadaan fizikal mereka berbanding pelajar normal dan semangat untuk belajar serta berjaya pada masa hadapan. Oleh yang demikian ini akan mendorong pelajar berkeperluan khas untuk sentiasa berkelakuan baik dan cuba tidak menambahkan masalah kepada guru-guru mereka. 
Selain itu, item melalui faktor beban tugas dari segi PdPc iaitu penyediaan Rancangan Pengajaran Harian (RPH) yang berbeza bagi pelajar berkeperluan khas dan pelajar normal amat berkaitan dengan kerenah pelajar. Pengkaji berpendapat bahawa guru PPI bagi Mata Pelajaran Vokasional perlu mengenali setiap tingkah laku, kekuatan dan kelemahan pelajar berkeperluan khas tersebut. Ini bagi memudahkan guru PPI untuk membuat RPH individu dan seterusnya mencapai objektif pengajaran. Masalah timbul apabila guru PPI menghadapi kekangan masa akibat bebanan tugas yang lain dan kerenah pelajar tersebut yang mungkin tidak mahu memberi kerjasama kepada guru PPI. Pendapat ini disokong oleh Noran et al., (2002) lebih-lebih lagi bagi subjek MPV guru PPI perlu sentiasa bersiap sedia dengan peralatan untuk amali dalam keadaan bebanan tugas lain dan kekangan masa untuk melakukan semua perkara dan ini menyebabkan guru akan mengabaikan pelajar berkeperluan khas tersebut kerana peralatan amali tersebut berkemungkinan tidak bersesuaian dengan pelajar tersebut.

\section{Kesimpulan}

Kajian mendapati bahawa faktor-faktor yang terdapat dalam tahap tekanan dan sikap pelajar berkeperluan khas telah menyumbang kepada peningkatan tahap tekanan dalam kalangan guru PPI. Oleh yang demikian, usaha menangani masalah tersebut secara bersepadu adalah diperlukan oleh pihak Kementerian Pelajaran, Jabatan Pelajaran Negeri, Pejabat Pelajaran Daerah dan sekolah serta guru untuk cuba mengatasinya. Antara faktor bagi tahap tekanan adalah beban tugas dari segi PdPc dan tugas-tugas sampingan yang melebihi had keupayaan. Ini terjadi apabila kekurangan kakitangan sokongan pentadbiran yang telah menyebabkan kerja-kerja perkeranian sebagai contoh mengisi borang pelajar, menyediakan sistem fail, memungut yuran dan kerja-kerja pentadbiran lain yang bukan di dalam bidang tugas pengajaran dan pembelajaran terpaksa dilakukan oleh guru. Justeru itu, bagi mengurangkan permasalahan tersebut pihak kementerian haruslah menambahkan bilangan kakitangan sokongan beserta dengan jumlah berat beban tugas yang perlu ditanggung bagi setiap kakitangan untuk mengelakkan terjadinya berlebihan bebanan tugas amat dialualukan. Melalui pertambahan kakitangan sokongan, secara tidak langsung dapat mengurangkan beban tugas guru PPI dan seterusnya dapat menumpukan sepenuh perhatian dalam pengajaran dan pembelajaran para pelajar.

Selain itu, pihak pentadbir harus memandang serius tentang suasana keadaan bilik PdPc dan bengkel. Dapatan kajian menunjukkan bahawa pengudaraan persekitaran kelas atau bengkel yang diajar oleh guru program PPI adalah tidak begitu selesa. Dalam keadaan cuaca negara Malaysia yang beriklimkan khatulistiwa dan terjadinya beberapa monsun yang mengundang peningkatan suhu kepanasan sesuatu bilik darjah dan bengkel. Apabila keadaan pengudaraan yang tidak selesa terjadi para guru dan para pelajar akan menghadapi masalah sewaktu PdPc berlangsung. Bukan itu sahaja, guru-guru PPI seharusnya meningkatkan motivasi diri, menanamkan sikap tolong menolong, bekerjasama dalam menyelesaikan sesuatu PdPc atau tugasan yang diberikan. Selain cuba menghormati akan perasaan, pendapat dan kritikan yang diberikan oleh rakan sekerjadengan hati yang terbuka dan berusaha untuk meningkatkan kelemahan yang terdapat dalam diri tersebut.

Di samping itu, penglibatan diri dalam kursus-kursus yang berkaitan dengan program PPI adalah amat penting dijalankan sebagai persediaan kepada para guru PPI lebih-lebih lagi bagi Mata Pelajaran Vokasional yang mempunyai komponen pembelajaran bahagian amali. Pentadbir perlu memandang perkara ini dengan penting agar keberkesanan PdPc dapat dilakukan dengan baik oleh para guru dan ini juga secara tidak langsung dapat mengurangkan tahap tekanan bagi guru-guru PPI serta mereka mengetahui tentang langkah-langkah untuk menangani pelajar berkeperluan khas tersebut. Jika perkara ini dipandang remeh oleh pentadbir, maka guru-guru tersebut akan berasa tidak yakin untuk melakukan pengajaran dan pembelajaran keatas pelajar berkeperluan khas dan akan menangani kerenah pelajar tersebut dengan teknik yang salah.

\section{Penghargaan}

Kajian ini sebahagiannya disokong oleh Universiti Tun Hussein Onn Malaysia, Johor. Sekalung ucapan terima kasih kepada rakan-rakan yang memberikan pandangan dan kepakaran yang sangat membantu dalam penyelidikan.

\section{Rujukan}

Adi Zuraini b. Md Zain (2003). “Tekanan Pembelajaran Di Kalangan Pelajar Pjj (UiTM)”. Tesis Msc, Universiti Utara Malaysia

Ahmad Azhari, A. (2010). Tahap Dan Punca Stres di Kalangan Guru-guru yang Mengajar Kemahiran Hidup di Negeri Perlis. Kertas Projek Ijazah Sarjana Muda Teknologi serta Pendidikan, Skudai: Universiti Teknologi Malaysia

Ali, R. M. D. R. (2011). Faktor-faktor yang mendorong tekanan kerja (stres) dikalangan guru-guru sekolah menengah di daerah Pasir Puteh (Doctoral dissertation, Open University Malaysia)

Ambotang, A.S \& Mohd Hashim, M.H. (2010). Hubungan Iklim Kerja Dan Tekanan Dalam Pengurusan Bilik Darjah Dalam Kalangan Guru Prasekolah. Journal of Techno-Social 
Bahagian Pendidikan Khas Kementerian Pelajaran Malaysia. (2008). Maklumat Pendidikan Khas 2008. Kuala Lumpur: Kementerian Pelajaran Malaysia

Bahagian Pendidikan Khas. (2013). Garis Panduan Program Pendidikan Inklusif Murid Berkeperluan Khas. Edisi percubaan. Kementerian Pendidikan Malaysia

Berita Harian. (2011). Lambakan Kerja Penyumbang Kepada Tekanan Hidup. Berita harian 27 September. m.s 1.

Berita Harian (2013). Guru Dakwa Suasana Kerja Tak Kondusi. Berita Harian 19 Jun

Bohari. M., Ahmad. F., dan Ramli. N. (2011). Pengaruh Efikasi Guru Pendidikan Khas Terhadap Penglibatan Murid, Amalan Pengajaran dan Pengurusan Bilik Darjah di Sekolah-Sekolah Pedalaman Sabah. Institut Pendidikan Guru Kampus Keningau

Chei, C.L. (2010). Tekanan Kerja Dalam Kalangan Guru-Guru Di Sebuah Sekolah Menengah Kerajaan Dan Sebuah Sekolah Menengah. Tesis (B.Ed), Serdang: Universiti Putra Malaysia

Datu Iskandar. (2013). Persepsi Guru Terhadap Masalah Disiplin Dan Tingkah Laku Pelajar Dalam Bilik Darjah Sekolah Menengah Kebangsaan Daerah Tawau, Sabah. Universiti Malaysia Sabah

Durkheim, G.D. (1987). Multimethod Research : A Synthesis of Styles. Beverly Hills:Sage

Fun, W.S (2008). Faktor Yang Mendorong Tekanan Kerja (Tekanan) Di Kalangan Guru-Guru SJK(C): Satu Kajian Di Tiga Buah Sekolah Di Wilayah Persekutuan. Kajian ilmiah. Universiti Teknologi Malaysia

Ghafar, M.N \& Jahaya, S. (2006). Bias Pengajaran Guru Dalam Pelajaran Khas Dan Pelajaran Normal. Universiti Teknologi Malaysia

Halim, S. (2013). Menentukan Faktor Tekanan Kerja Guru Sekolah Mengah Gred A Daerah Batu Pahat. Universiti Tun Hussein Onn Malaysia

Hashim, O. \& Ibrahim, A.G. (2007). Ke Arah Meningkatkan Pengajaran Dan Pembelajaran Pendidikan Seni Dalam Pendidikan Khas Bermasalah Pembelajaran. Jurnal Masalah Pendidikan, 30(1): 37-49

Hatib, A., Rosmin, N., \& Bin, N. (2016). Kebolehpasaran Bakal Graduan Lepasan Kolej Vokasional : Sudut Pandang Industri. Creative, Technology \& Entrepreneurship Conference 2016

Ishak, H., Ab Halim Tamuri, R. A. M., \& Bari, S. (2012). Amalan Pengajaran Guru dalam Pengajaran dan Pembelajaran Pendidikan Islam di Sekolah Kebangsaan Pendidikan Khas (Masalah Pendengaran). JIAE: Journal of Islamic and Arabic Education, 2(4), 11-24

Kassan, Z. dan Abdullah, S. (2015). Pendidikan Disleksia. Cetakan 2015. Gains Print Sdn. Bhd. Sasbadi Sdn. Bhd. Kementerian Kesihatan Malaysia. (2002). Kempen Cara Hidup Sihat. Laporan Tahunan Program Kesihatan Malaysia, 23-30

Kyriacou, C. (2001). Teacher's Stress and Burnout: An International Review. Education Research, 29(2): $146-152$.

Landell. (1997). Analisis Diskriptif Bagi Melihat Tahap Pengamalan Gaya Hidup Sihat. Diambil daripada < https://www.coursehero.com/file/p1li1s5/42-Analisis-Diskriptif-Bagi-melihat-tahap-pengamalan-gaya-hidup-sihat-di/>

Lee. (2010). Rancangan Pendidikan Individual, Rancangan Pegajaran Harian \& Rancangan Pengajaran Individu. Buletin Pendidikan Khas. Jilid2, bil 1/2010. Universiti Sains Malaysia.

Lewis, R.B. dan Doorlag, D.H. (2003) Teaching Special Students in General Educations Classrooms. New Jersey: Pearson Education, Inc

Manthei, R, and Solman, R. (2005). Teacher Tekanan and Negative Outcomes in Canterbury State Schools. New Zealand Journal of Educational Studies 
Mohd. Amin, N. \& Mohd Yasin, M.H. (2016). Pelaksanaan Program Pendidikan Inklusif Murid Berkeperluan Khas Dalam Pelan Pembangunan Pendidikan Malaysia 2013-2015. National University Of Malaysia. International Conference On Special Education In Southeast Asia Region 6 ${ }^{\text {th }}$ Series 2016

Mohd. Hasidin Zaini. (2002). Faktor Ciri-Ciri Kerja Yang Mempengaruhi Tekanan Guru: Kajian Di Kalangan Kakitangan Sumber Kemahiran Hidup Sekolah Menengah Negeri Johor. Tesis Sarjana Pengurusan Teknologi. Universiti Teknologi Malaysia

Mok, S.S. (2010). Pemulihan, Pengayaan dan Isu Pendidikan. Kuala Lumpur : Dewan Bahasa dan Pustaka

Noran, F., Lope Pihie, Z.A. \& Mahyuddin, R. (2002). Stres di Kalangan Guru Wanita yang Mengajar Mata Pelajaran Kemahiran Hidup. Pertanika J. Soc. Sci. \& Hum. 9(2): 95 - 101. ISSN: 0128-7702. Universiti Putra Malaysia Press

Othman.N \& Md Omar.H. (2014). Beban Tugas Dan Motivasi Pengajaran Guru Di Sekolah Menengah Daerah Ranau. Jurnal Pemikir Pendidikan (Journal for Education Thinkers). Vol. 5,pp. 35-57, ISSN 1985-3637. Universiti Malaysia Sabah

Othman, N.M. (2014). Pengaruh Tahap Tekanan Terhadap Kepuasan Kerja Dalam Kalangan Pengajar Kolej Vokasional Di Negeri Pahang. Universiti Tun Hussien Onn Malaysia

Said Ambotang, Pilus, N. \& Abdullah, Q. (2015). Hubungan Kerenah Pelajar dan Beban Tugas dengan Tahap Stres Guru di Sekolah Menengah. Universiti Malaysia Sabah

Sidi, H. dan Shaharom, M.H. (2002). Mengurus Stres: Pendekatan Yang Praktikal. Kuala Lumpur: Dewan Bahasa dan Pustaka

Sipon.S (2007). Pendidik Mesti Bijak Kawal Emosi. Dalam “Utusan Malaysia”. 27 Julai 2007

Saion, R. (2014). Persepsi Guru-Guru Kemahiran Hidup Bersepadu Terhadap Literasi Pentaksiran Dalam Pelaksanaan Pentaksiran Berasakan Sekolah. Universiti Tun Hussien Onn

Salamanca. (1994). The Salamanca Statement And Framework For Action On Special Needs Education. World Conference On Special Needs Education: Accesss And Quality. Ministry Of Education And Science Spain

Tang, T., \& Yeung, A. (1999). Hong Kong Teachers' Sources Of Tekanan, Burnout And Job Satisfaction. Retrieved from EBSCOhost

Trendall, C. (1989). Tekanan ini Teaching and Teacher Effectiveness: A Study of Teachers Across Mainstream and Special Educational Research. 31 (1): 52-58

Utusan Malaysia. (2012). Guru Dikenal Pasti Berdepan Masalah Mental. Kuala Lumpur

Ustazkenli (2012). Instrument kajian. dicapai pada Jun 8, 2012

Yahaya, A. \& Aliju, M.J. (2001). Teori-teori Tingkah laku Negatif. Univertisi Teknologi Malaysia

Yahaya, R., Ghani, M.Z, Che Aman, R.. Che Ahmad, R., Mohd Isa, Z., Ismail, H., Hamzah, A. (2010). Tekanan Dalam Kalangan Guru Pendidikan Khas. Pusat Pengajian Ilmu Pendidikan. Universiti sains Malaysia

Yahaya, A., Ramli, J. \& Ismail, M. (2010). Tekanan Dalam Kalangan Guru Sekolah Menengah di Empat Buah Negeri di Malaysia. Asia Pacific Journal of Educators and Education. Vol. 25, 103-136, 2010

Zaiha (2014). Kompetensi Guru Dalam Pengajaran Amali Reka Bentuk Dan Teknologi Di Sekolah Rendah Daerah Batu Pahat. Universiti Tun Hussein Onn Malaysia

Zakaria, U. (2014). Faktor-Faktor Yang Mempengaruhi Tekanan Kerja Dalam Kalangan Guru Sekolah Menengah Daerah Hulu Terengganu, Terengganu Darul Iman. Universiti Utara Malaysia 